\title{
EMOTIONAL CONDITION AND PHYSICAL ACTIVITY OF FIRST-YEAR FEMALE STUDENTS AT MEDICAL COLLEGE DURING THE ACADEMIC YEAR
}

\author{
Semenova Nataliia ${ }^{1}$, Mahlovanyi Anatolii ${ }^{2}$ \\ ${ }^{1}$ Lviv Medical College at Danylo Halytskyi Lviv National Medical University, \\ ${ }^{2}$ Danylo Halytskyi Lviv National Medical University
}

Accepted for publication: 15.06 .2017

Published: 25.06.2017

DOI: 10.17309/tmfv.2017.2.1190

\begin{abstract}
The objective is to establish emotional state changes among female students during the academic year regarding available physical activity.

Material \& methods: the study involved 65 first year femalestudents of medical college at Danylo Halytskyi Lviv National Medical University.

To achieve the tasks set the study relied on the following methods: analysis and synthesis of scientific and technical literature, pedagogical observation, methods of mathematical statistics ( $t$-Student test for independent samples), SAN method.

Results: no reliable differences found when comparing indicators of activity and mood at the beginning and end of the academic year. The obtained results of the survey indicate medium and high evaluationof SAN categories at low levels of physical activity.

Conclusions: state of health, activity and mood levelswere rated with middle and high scoresbyfemale students. SAN evaluation dynamics has been lowering during the academic year, and the activity level of female students was significantly lower than that ofstate of health as well as mood. The resulting index of activity level as emotional characteristic largely reflects low physical activity of female students.

Key words: SAN (the state of health, activity and mood); female students; motor activity.
\end{abstract}

\section{Introduction}

Nowadays studying at higher educational establishments of all levels of accreditation is highly demandingfor health and physical performance of students. According to the authors [Apanasenko H. L., Popova L. A., Mahlovanyi A. V., 2011; Semenova N. V., 2015] training of specialists along with other factors depends on their health. However, our previous study [Semenova N. V., 2015; Semenova N. V., Mahlovanyi A.V., 2015] has indicated that somatic health of most female students is of below middle and low level. One of the important factors that have a significant impact on health is emotional state.

Analysis of research by various authors [Apanasenko H. L., Popova L. A., Mahlovanyi A. V., 2012; Oleksenko V. M., 2011; Yadwiha Y. P., 2011] confirms the relationship between physical health, emotional state and physical activity of students. The studies have proved positive effects of different types of physical activity, e.g. recreational activities at bowling

(C) Semenova Nataliia, Mahlovanyi Anatolii, 2017. clubs [Andreev O., Patsaliuk K., 2012], aqua aerobics [Yaroshik M. Ya., 2012; Usov O. V, Romaniuk Yu. V., Kopytina Ya. M., 2014] and the system of physical exercises by J. Pilates [Nakonechna A., 2014], on the indexof emotional state of students, women and men. However, analysis of the scientific and methodological literature revealed a few studies [Semenova N. V., Mahlovanyi A. V., 2015] devoted to thecorrelation between emotional state and physical activity of female students at universities of I-II levels of accreditation.

Analysis of the scientific and methodological literature shows that the study ofphysical activity and emotional state of female students enrolled at the level ofunfinished secondary education is not fully explored and is relevant. Psychological processes and behavior of female students at this age, psychoemotional experiences associated with the completion of the biological and physiological development as well as adaptation to new learning conditions and living environment reflect on their emotional state, therefore the identified problem requires further research.

The aim of the research.The aim of the research is to determine changes in emotional state of first-year 
female students during the academic year regarding available physical activity.

\section{Material \& methods}

\section{Objectives of the research.}

1. To identify emotional state of first-year female students.

2. To analyze and describe the dynamics of the state of health, activity and mood among first-year female students during the academic year.

3. To set existing relationship between available physical activity and emotional state of female students.

The above-listed objectives have been fulfilled by applying the following methods and techniques: analysis and synthesis of scientific and methodological literature, pedagogical observation, methods of mathematical statistics ( $t$-Student test for independent samples), SAN method.

Organization of the research. In the 2015-2016 academic year the survey was conducted according to SAN method (the state of health, activity and mood) among 65 first-year female students of Lviv Medical College at Danylo Halytskyi Lviv National Medical University. The survey was accomplished in two stages: at the beginning of the academic year (Stage I) and at the end of the academic year (Stage II).

SAN method is a kind of questionnaires of moods and states developed by Doskin V. A., Lavrentiieva N. A., Sharai V. B., Miroshnikov M. P. (1973) for evaluation of human emotional state at the time of the survey. SAN is a map (table) containing 30 pairs of opposite characteristics that reflect the features under study of emotional state (the state of health, activity and mood). Students were asked to choose the description that meets their condition in each pair, as well as the number that corresponds to the degree (strength) of its expression. The total number of points for each of the criteria was within 10-70 points. Estimates that exceed 40 points showed a favorable state of participants and evaluated it as average; those below 40 points showed poor condition and score their state assessment as low, those in the range of 50 points and above showed high appreciation of their own state.

\section{Results of the research}

The results revealed that the arithmetic mean of indicators of the state of health, activity and mood amongfirst-year female students corresponded to middle and high scores. Indicators of the state of health were within 24-68 points at the beginning of the academic year and 20-66points at the end, activity was ranged within 29-67 points at the beginning of the academic year and 24-65 points at its end, mood indicators were given $34-70$ points at the beginning and 24-69 points at the end of the academic year (Table. 1).

Evaluation of their own emotional stateby female students at the beginning of the academic year revealed that low scores were given regarding the state of health, activity and mood by three, six people and two students respectively. At the end of the academic year an increase in the number of students who rated their state of health and activity with low scores was observed. Low evaluation of mood and activity increased twice, low evaluation of mood remained unchanged. Number of students that evaluated their activity with high points reduced significantly. This figure fell by $7.7 \%$ during the year. Slight decrease in the number of high marks regarding state of health and mood by $1.6 \%$ and $1.5 \%$ respectively was observed. Number of students who evaluated their state of health and activity as average decreased by $3.1 \%$ and $1.5 \%$ respectively, but while evaluating the mood average scores increased by $1.5 \%$ (Table 2).

Analysis of the data revealed that at the beginning as well as at the end of the academic year students'mood index was significantly higher than that of the state of health and activity (Table. 3 ).

However, the activity level of all female students during the academic year was significantly lower than that of the state of health and mood (Fig. 1).

Comparing the data obtained at the beginning and at the end of the academic year showed that the level of the state of health, activity and mood slightly decreased.

Table 1. Evaluation of female students' state of health, activity and mood (points)

\begin{tabular}{lllllll}
\hline \multirow{2}{*}{$\begin{array}{l}\text { Stages } \\
(\mathrm{n}=65)\end{array}$} & \multicolumn{2}{l}{ State of Health } & \multicolumn{2}{l}{ Activity } & \multicolumn{3}{l}{ Mood } \\
\cline { 2 - 7 } & Min & Max & Min & Max & Min & Max \\
\hline Stage I & 24 & 68 & 29 & 67 & 34 & 70 \\
Stage II & 20 & 66 & 24 & 65 & 24 & 69
\end{tabular}

Note: min - minimum score; max - maximum score

Table 2. Evolution of SAN (\%)

\begin{tabular}{llllllllll}
\hline \multirow{2}{*}{ Stages } & \multicolumn{3}{l}{ State of Health } & \multicolumn{3}{c}{ Activity } & \multicolumn{4}{c}{ Mood } \\
\cline { 2 - 10 } & H & M & L & H & M & L & H & M & L \\
\hline Stage I & 75,4 & 20 & 4,6 & 53,8 & 36,9 & 9,2 & 89,2 & 7,7 & 3,1 \\
Stage II & 73,8 & 16,9 & 9,2 & 46,1 & 35,4 & 18,5 & 87,7 & 9,2 & 3,1
\end{tabular}

Note: $\mathrm{H}$-high score,M-middlescore, L-lowscore

Table 3. Dynamics of female students' evaluation at different stages $(X \pm m)$

\begin{tabular}{cccc}
\hline Stages & State of Health & Activity & Mood \\
\hline I & $54,97 \pm 1,14$ & $49,60 \pm 1,01$ & $59,31 \pm 1,12^{\star}$ \\
II & $53,26 \pm 1,30$ & $47,63 \pm 1,16$ & $58,72 \pm 1,06^{\star}$
\end{tabular}

Note: ${ }^{*}$-significant differences between indicators 


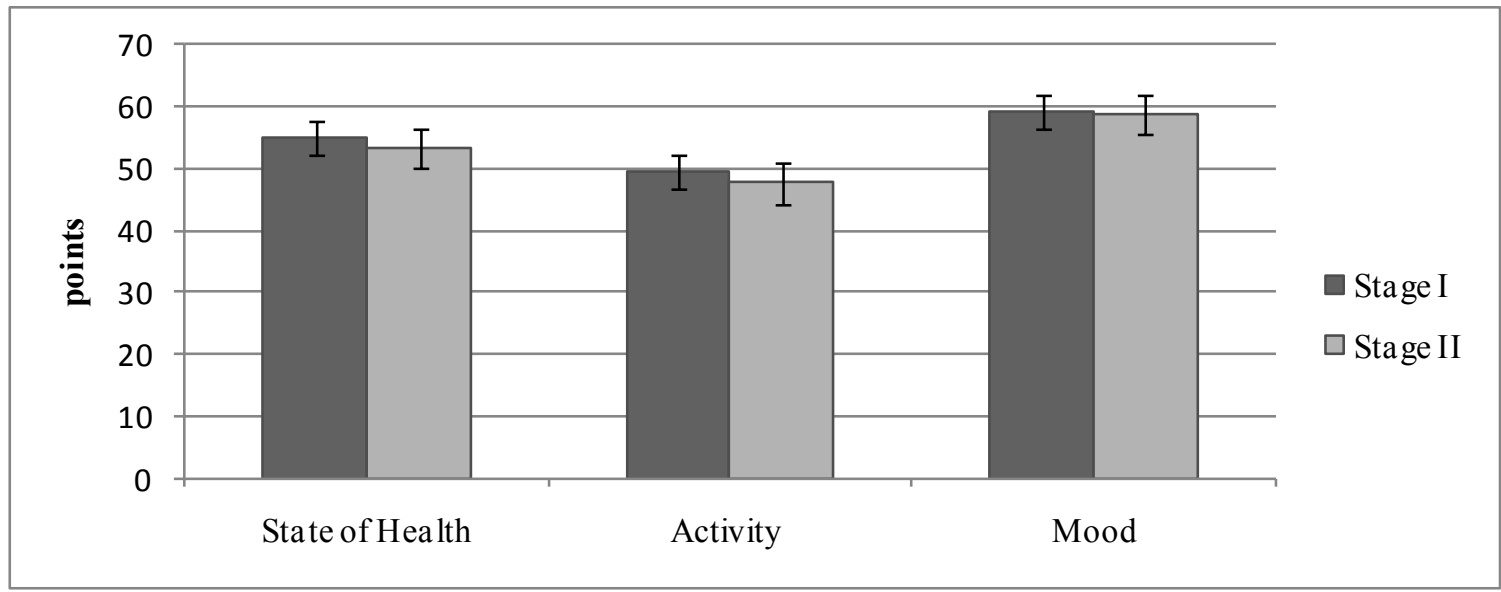

Fig. 1 Indicators of SAN levels during the academic year

\section{Discussion of the research results}

The obtained results indicate medium and high level of students' state of health, activity and mood assessment at the existing low level of physical activity. It should also be noted that the level of activity of female students at the beginning and at the end of the academic year was significantly lower than the other parameters under survey, although the average rate corresponded to middle and high assessment of their activity. The level of activity as emotional characteristics also reflects the current level of physical activity of female students. Lack of acquired need for regular physical activity and sport while at school results in passive attitude towards physical activity at college, personal physical training and physical perfection while studying at higher educational institutions. Conditions for physical education created at higher educational institutions of I-II levels of accreditation, the current curriculum of physical education can not compensate for the lack of motor activity among students. As a result female students' physical activity is limited to mandatory physical education lessons for 2 hours per week that confirm previous studies of motor activity of the phenomenon among female students [Ujević, T., Sporis, G., Milanović, Z., Pantelić, S., \& Neljak, B., 2013; Semenova N. V., 2015; Semenova N. V., Mahlovanyi A. V., 2015; Ivashchenko, O.V., 2016;
Ivashchenko, O., Khudolii, O., Iermakov, S., Lochbaum, M., Cieślicka, M., Zukow, W., Nosko, M., \& Yermakova, T., 2017; ].

Prospects for further research are in determining the emotional condition of female students enrolled in studying on the basis of base secondary education (9 school years), during different periods of studying as well as dynamics of SAN index under the influence of physical activity or its absence.

\section{Conclusions}

It has been discovered that state of health, activity and mood were rated with middle and high scores by female students. SAN dynamics lowering during the academic year was observed and the activity level of female students was significantly lower than that of both state of health and mood. The resulting index of activity as an emotional state characteristic largely reflects low physical activity of female students.

\section{Conflict of interests}

The authors declare that there is no conflict of interests.

\section{Література}

1. Андрєєва, О., \& Пацалюк, К. (2012). Соціально-педагогічні умови організації рекреаційної діяльності боулінг-клубів. Фізичне виховання, спорт і культура здоров'я у сучасному суспільстві, 4(20), 223-229.

2. Апанасенко, Г.Л., Попова, Л.А. \& Магльований, А.В. (2011). Санологія (медичні аспекти валеології): підручник для лікарів-слухачів закладів (факультетів) післядипломної освіти. Львів: ПП «Кварт».

\section{References}

1. Andrieieva, O. \& Patsaliuk, K. (2012). Sotsialnopedahohichni umovy orhanizatsii rekreatsiinoi diialnosti boulinh-klubiv. Fizychne vykhovannia, sport i kultura zdorovia u suchasnomu suspilstvi, 4(20), 223-229.

2. Apanasenko, H.L., Popova, L.A. \& Mahlovanyi, A.V. (2011). Sanolohiia (medychni aspekty valeolohii): pidruchnyk dlia likariv-slukhachiv zakladiv (fakultetiv) pisliadyplomnoi osvity. Lviv: $P P$ «Kvart». 
3. Апанасенко, Г.Л., Попова, Л.А. \& Магльований, А. В. (2012). Саналогия. Основы управления здоровьем : монография. LAMBERT, 404.

4. Москаленко, Н., Сичова, Т. \& Анастасьєва, 3. (2012). Інноваційні технології фізичного виховання, спрямовані на зміцнення здоров'я студенток 17-18 років. Спортивний вісник Придніпров'я, (2), 10-13.

5. Наконечна, А. (2014). Психоемоційний стан жінок другого зрілого віку, які займаються за системою Дж. Пілатеса. Молода спортивна наука України, 18 (4), 88-92.

6. Олексенко, В.М. (2011). Фактори збереження й зміцнення здоров'я за педагогічними технологіями. Педагогіка, психологія та медико-біологічні проблеми фізичного виховання і спорту, (1), 95-97.

7. Семенова, Н.В. (2011). Взаємозв'язок рухової активності і соматичного здоров'я студенток 15-17 років. Науково-педагогічні проблеми фізичної культури (фізична культура і спорт), (13), 563-567.

8. Семенова, Н.В. (2015). Обгрунтування режиму рухової активності студенток 15-17 років з різним рівнем соматичного здоров'я. Автореф. дис. ... канд. наук з фіз. виховання та спорту : 24.00.02.

9. Семенова, Н. \& Магльований, А. (2015). Рухова активність та психоемоційний стан студенток 15-17 років. Фізичне виховання, спорт і культура здоров'я у сучасному суспільстві, 2 (30), 95-99.

10. Усова, О.В., Романюк, Ю.В. \& Копитіна, Я.М. (2014). Вплив аквааеробіки на формування та збереження здоров'я студенток вищих навчальних закладів. Вісник Чернігівського національного педагогічного університету. Сер. : Педагогічні науки. Фізичне виховання та спорm, 118(3). Режим доступу: http:// nbuv.gov.ua/j-pdf/VchdpuPN_2014_118(3)_71.

11. Ядвіга, Ю.П. (2011). Фізичне виховання студентів вищого навчального закладу економічного профілю в період трансформації вищої освіти України в європейський простір. Автореф. дис ... канд. наук 3 фізичного виховання та спорту: 24.00.02.

12. Ярошик, М.Я. (2012). Вплив фізкультурно-оздоровчих занять аквафітнесом на емоційний стан жінок другого зрілого віку. Здоровье для всех: материалы IV Международной научно-практической конференции, УО «Полесский государственный университет», г. Пинск, 26-27 апреля 2012 г., 2, 112-117.

13. Ivashchenko, O.V. (2016). Methodic of pedagogic control of 16-17 years' age girls' motor fitness. Pedagogics, psychology, medical-biological problems of physical training and sports, 5, 26-32. doi:10.15561/18189172.2016.0504

14. Ivashchenko, O., Khudolii, O., Iermakov, S., Lochbaum, M., Cieślicka, M., Zukow, W., Nosko, M. \& Yermakova, T. (2017). Methodological approaches to pedagogical control of the functional and motor fitness of the girls from 7-9 grades. Journal of Physical Education and Sport ๑ (JPES), 17 (1), 254-261.

15. Ujević, T., Sporis, G., Milanović, Z., Pantelić, S. \& Neljak, B. (2013). Differences between health related physical fitness profiles of Croatian children in urban and rural areas. Coll Antropol. 37(1), 75-80.
3. Apanasenko, G.L., Popova, L.A. \& Maglovanyi, A.V (2012). Sanalogiia. Osnovy upravleniia zdorovem : monografiia. LAMBERT, 404.

4. Moskalenko, N., Sychova, T. \& Anastasieva, Z. (2012). Innovatsiini tekhnolohii fizychnoho vykhovannia, spriamovani na zmitsnennia zdorovia studentok 17-18 rokiv. Sportyvnyi visnyk Prydniprovia, (2), 10-13.

5. Nakonechna, A. (2014). Psykhoemotsiinyi stan zhinok druhoho zriloho viku, yaki zaimaiutsia za systemoiu Dzh. Pilatesa. Moloda sportyvna nauka Ukrainy, 18 (4), 88-92.

6. Oleksenko, V.M. (2011). Faktory zberezhennia y zmitsnennia zdorovia za pedahohichnymy tekhnolohiiamy. Pedahohika, psykholohiia ta medyko-biolohichni problemy fizychnoho vykhovannia i sportu, (1), 95-97.

7. Semenova, N.V. (2011). Vzaiemozviazok rukhovoi aktyvnosti i somatychnoho zdorovia studentok 15-17 rokiv. Naukovo-pedahohichni problemy fizychnoi kultury (fizychna kultura i sport), (13), 563-567.

8. Semenova, N.V. (2015). Obgruntuvannia rezhymu rukhovoi aktyvnosti studentok 15-17 rokiv z riznym rivnem somatychnoho zdorovia. Avtoref. dys. ... kand. nauk $\mathrm{z}$ fiz. vykhovannia ta sportu : 24.00.02.

9. Semenova, N. \& Mahlovanyi, A. (2015). Rukhova aktyvnist ta psykhoemotsiinyi stan studentok 15-17 rokiv. Fizychne vykhovannia, sport i kultura zdorovia u suchasnomu suspilstvi, 2 (30), 95-99.

10. Usova, O.V., Romaniuk, Yu.V. \& Kopytina, Ya.M. (2014). Vplyv akvaaerobiky na formuvannia ta zberezhennia zdorovia studentok vyshchykh navchalnykh zakladiv. VisnykChernihivskoho natsionalnohopedahohichnoho universytetu. Ser. : Pedahohichni nauky. Fizychne vykhovannia ta sport, 118(3). Rezhym dostupu: http:// nbuv.gov.ua/j-pdf/VchdpuPN_2014_118(3)_71.

11. Yadviha, Yu.P. (2011). Fizychne vykhovannia studentiv vyshchoho navchalnoho zakladu ekonomichnoho profiliu v period transformatsii vyshchoi osvity Ukrainy v yevropeiskyi prostir. Avtoref. dys ... kand. nauk z fizychnoho vykhovannia ta sportu: 24.00.02.

12. Yaroshyk, M.Ya. (2012). Vplyv fizkulturnoozdorovchykh zaniat akvafitnesom na emotsiinyi stan zhinok druhoho zriloho viku. Zdorove dlia vsekh: materialy IV Mezhdunarodnoi nauchno-prakticheskoi konferentcii, UO «Polesskii gosudarstvennyi universitet», g. Pinsk, 26-27 aprelia 2012 g., 2, 112-117.

13. Ivashchenko, O.V. (2016). Methodic of pedagogic control of 16-17 years' age girls' motor fitness. Pedagogics, psychology, medical-biological problems of physical training and sports, 5, 26-32. doi:10.15561/18189172.2016.0504

14. Ivashchenko, O., Khudolii, O., Iermakov, S., Lochbaum, M., Cieślicka, M., Zukow, W., Nosko, M. \& Yermakova, T. (2017). Methodological approaches to pedagogical control of the functional and motor fitness of the girls from 7-9 grades. Journal of Physical Education and Sport ه (JPES), 17 (1), 254-261.

15. Ujević, T., Sporis, G., Milanović, Z., Pantelić, S. \& Neljak, B. (2013). Differences between health related physical fitness profiles of Croatian children in urban and rural areas. Coll Antropol. 37(1), 75-80. 


\title{
ПСИХОЕМОЦІЙНИЙ СТАН І РУХОВА АКТИВНІСТЬ СТУДЕНТОК I КУРСУ МЕДИЧНОГО КОЛЕДЖУ ВПРОДОВЖ НАВЧАЛЬНОГО РОКУ
}

\author{
Наталія Семенова ${ }^{1}$, Анатолій Магльований ${ }^{2}$ \\ ${ }^{1}$ Медичний коледж Львівського національного медичного університету \\ ім. Данила Галицького \\ ${ }^{2}$ Львівський національний медичний університет ім. Данила Галицького \\ Реферат. Статья: 5 с., 3 табл., 1 рис., 15 источников.
}

Мета дослідження - встановити зміни психоемоційного стану студенток I курсу упродовж навчального року за наявної рухової активності.

Матеріали і методи: у дослідженні взяли участь 65 студенток I курсу медичного коледжу Львівського національного медичного університету імені Данила Галицького. Для вирішення поставлених завдань було використано наступні методи та методики: аналіз та узагальнення наукової та методичної літератури, педагогічне спостереження, методи математичної статистики (t-критерій Стьюдента для незалежних виборок), методика САН.

Результати дослідження: встановлено відсутність достовірної розбіжності при порівнянні показників самопочуття, активності і настрою на початку і наприкін- ці навчального року. Отримані результати опитування вказують на середній і високий рівень параметрів САН при низькому рівні рухової активності.

Висновки: встановлено, що самопочуття, активність та настрій студентки I курсу оцінили середніми та високими балами. Отримано динаміку зниження рівня САН впродовж навчального року, при цьому рівень активності студенток був достовірно меншим за показники як самопочуття, так і настрою. Отриманий показник активності, як психоемоційна характеристика у значній мірі відображає низьку рухову активність студенток.

Ключові слова: САН (самопочуття активність, настрій); студентки; рухова активність.

\section{ПСИХОЭМОЦИОНАЛЬНОЕ СОСТОЯНИЕ И ДВИГАТЕЛЬНАЯ АКТИВНОСТЬ СТУДЕНТОК I КУРСА МЕДИЦИНСКОГО КОЛЛЕДЖА НА ПРОТЯЖЕНИИ УЧЕБНОГО ГОДА}

\author{
Наталия Семёнова ${ }^{1}$, Анатолий Маглёваный ${ }^{2}$ \\ ${ }^{1}$ Медицинский колледж Львовского национального медицинского университета \\ им. Данила Галицького \\ ${ }^{2}$ Львовский национальный медицинский университет им. Данила Галицького \\ Реферат. Статья: 5 с., 3 табл., 1 рис., 15 источников.
}

Цель исследования - установить изменения психоэмоционального состояния студенток I курса в течение учебного года при наявной двигательной активности.

Материалы и методы: в исследовании приняли участие 65 студенток I курса медицинского колледжа Львовского национального медицинского университета имени Данила Галицкого. Для решения поставленных задач были использованы следующие методы и методики: анализ и обобщение научной и методической литературы, педагогическое наблюдение, методы математической статистики (t-критерий Стьюдента для независимых выборок), методика САН.

Результаты исследования: установлено отсутствие достоверного отличия при сравнении показате- лей самочувствия, активности и настроения в начале и в конце учебного года. Полученные результаты опроса указывают на средний и высокий уровень параметров САН при низком уровне двигательной активности.

Выводы: установлено, что самочувствие, активность и настроение студентки I курса оценили средними и высокими баллами. Получено динамику снижения уровня САН в течение учебного года, при этом уровень активности студенток был достоверно меньше показателей как самочувствия, так и настроения. Полученный показатель активности, как психоэмоциональная характеристика в значительной степени отражает низкую двигательную активность студенток.

Ключевые слова: САН (самочувствие, активность, настроение); студентки; двигательная активность.

\section{Інформація про авторів:}

Семенова Наталія: sem_nat@bk.ru; Медичний коледж Львівського національного медичного університету ім. Данила Галицького; вул. Судова, 7, Львів, 79000. Україна. Магльований Анатолій: sem_nat@bk.ru; Львівський національний медичний університет ім. Данила Галицького; вул. Пекарська, 69, Львів, 79000. Україна.
Цитуйте статтю як: Semenova, Nataliia \& Mahlovanyi, Anatolii (2017). Emotional condition and physical activity of first-year female students at medical college during the academic year. Teoria ta metodika fizicnogo vihovanna, 17 (2), 62-67. doi:10.17309/tmfv.2017.2.1190

Стаття надійшла до редакції: 15.05.2017 р. Прийнята: 15.06.2017 р. Надрукована: 25.06.2017 р. 